\title{
Chemical composition and nutritive value of hot pepper seed (Capsicum annuum) grown in Northeast Region of China
}

\author{
Yu ZOU ${ }^{1 *}$, Kun MA ${ }^{1}$, Mixia TIAN ${ }^{1}$
}

\begin{abstract}
Chemical composition and nutritive value of hot pepper seeds (Capsicum annuum) grown in Northeast Region of China were investigated. The proximate analysis showed that moisture, ash, crude fat, crude protein and total dietary fiber contents were 4.48, 4.94, 23.65, 21.29 and $38.76 \mathrm{~g} / 100 \mathrm{~g}$, respectively. The main amino acids were glutamic acid and aspartic acid (above $2 \mathrm{~g} / 100 \mathrm{~g}$ ), followed by histidine, phenylalanine, lysine, arginine, cysteine, leucine, tryptophan, serine, glycine, methionine, threonine and tyrosine $(0.8-2 \mathrm{~g} / 100 \mathrm{~g})$. The contents of proline, alanine, valine and isoleucine were less than $0.8 \mathrm{~g} / 100 \mathrm{~g}$. The fatty acid profile showed that linoleic acid, palmitic acid, oleic acid, stearic acid and linolenic acid (above $0.55 \mathrm{~g} / 100 \mathrm{~g}$ ) as the most abundant fatty acids followed lauric acid, arachidic acid, gondoic acid and behenic acid (0.03-0.15 g/100 g). Analyses of mineral content indicated that the most abundant mineral was potassium, followed by magnesium, calcium, iron, zinc, sodium and manganese. The nutritional composition of hot pepper seeds suggested that they could be regarded as good sources of food ingredients and as new sources of edible oils.
\end{abstract}

Keywords: hot pepper seed; proximate composition; amino acid composition; fatty acid profile; mineral element content.

Practical Application: Hot pepper seeds can be potentially used as good sources of food ingredients and edible oils.

\section{Introduction}

Hot peppers (Capsicum annuum.) belong to the Solanaceae and grow widely in various parts of the world especially in the temperate regions. Among hot pepper producing countries, China is the leading producer followed by Mexico and Turkey with above 1,745,000 tons of produce per year (Firatligil-Durmus \& Evranuz, 2010). Hot pepper is widely used as a flavoring and for nutritional purposes. Hot pepper seeds are separated from the pods after eating or processing the flesh. Worldwide, millions of tons of hot pepper seeds from food processing are generated. Some of them are used as animal feed but most of them are still discarded without treatment leading to the environment pollution (Jarret et al., 2013).

Recently, more attention has been focused on the utilization of food processing by-products and wastes, as well as under utilized agricultural products. Such utilization would contribute to maximizing available resources and result in the production of various new foods (El-Adawy \& Taha, 2001). A number of studies report that hot pepper seeds are rich in proteins, fats and minerals (Park et al., 2006). These nutritional constituents, particularly essential amino acids and essential fatty acids, are necessary nutrients for the maintenance of healthy body (Koyuncu et al., 2014). Thus, hot pepper seeds may be an inexpensive source of dietary proteins, fats and minerals.

Factors like cultivars and environmental conditions have influence on the nutritional constituents of hot peppers and hot pepper seeds (Bae et al., 2012). In literatures, there are several reports about the chemical composition of the divergent hot pepper seeds grown under different ecological conditions in Egypt, United States and Korea (El-Adawy \& Taha, 2001; Jarret et al., 2013; Park et al., 2006). However, there is little information available about nutritional constituents of hot pepper seeds grown in China. Therefore, the specific objective of this study was to evaluate chemical composition and nutritive value of hot pepper seeds (Capsicum annuum) grown in the Northeast Region of China. In addition, the potential for the utilization of this by-product in the food industry was discussed.

\section{Materials and methods}

\subsection{Material}

The seeds of hot pepper cultivar (Capsicum annuum cv. 'Jinta') were harvested from the Northeast Region of China in September 2014, and dried in a vacuum drying chamber (DZF-6050, Jinyou Experimental Equipment Co. Ltd., Shanghai, China) at $40{ }^{\circ} \mathrm{C}$ for $24 \mathrm{~h}$. After dehydration, hot pepper seeds were pulverized (FSD-100A, Woliang grain and oil equipment Co. Ltd., Taizhou, China) for $2 \mathrm{~min}$, and sifted through a $0.15 \mathrm{~mm}$ sieve. The resulting powder was stored in dark bags at $-20^{\circ} \mathrm{C}$ to prevent moisture contamination and to protect the powder from light. All standards used in the experiments were purchased from Sigma-Aldrich Chemical Co. (St. Louis, Mo, USA). All other reagents were obtained from Sinopharm Chemical Regent Co., Ltd. (Shanghai, China) and were of analytical grade. 


\subsection{Proximate analysis}

In accordance with method of Aberoumand (2014), moisture was determined by weight loss after heating in blast drying oven (DHG-9640A, Hecheng Instrument Co. Ltd., Shanghai, China) at $105^{\circ} \mathrm{C}$, ash in a muffle furnace (QSH-1700M, Quanshou Electic Furnace Co. Ltd., Shanghai, China) at $550{ }^{\circ} \mathrm{C}$ for $5 \mathrm{~h}$. Crude fat was estimated by exhaustive extraction with petroleum ether using Soxhlet apparatus according to Herch et al. (2014). Crude protein was calculated from nitrogen, determined by Kjeldahl method, multiplying the value by 6.25 as recommended by Koyuncu et al. (2014). Total dietary fiber was obtained by adding the soluble and insoluble fractions, according to the enzymaticgravimetric method of Prosky et al. (1988).

\subsection{Determination of amino acid composition}

Amino acid composition analysis was performed by the method previously described by Tu et al. (2009) with a minor modification. Briefly, the sample $(100 \mu \mathrm{g})$ was heated in $0.4 \mathrm{~mL}$ of $6 \mathrm{M} \mathrm{HCl}$ at $120^{\circ} \mathrm{C}$ for $24 \mathrm{~h}$ in an evacuated and sealed tube. The hydrolysate was evaporated to dryness in a vacuum and was dissolved in $800 \mu \mathrm{L}$ of a pH 2.2 buffer for amino acid composition analysis using an amino acid analyzer (L-8800, Hitachi Ltd., Tokyo, Japan). Standard amino acids were used for identification. The chromatograms were recorded and the area of individual peak was calculated. The amino acids were identified by comparing their retention times with standards and the area under the peaks correspond to the amounts of amino acids present in the sample.

\subsection{Fatty acid profile analysis}

The lipid fractions were initially subjected to esterification of fatty acids, which were converted to fatty acid methyl esters using the method described by Hartman \& Lago (1973). The analysis of fatty acid methyl esters was performed using a Agilent $6890 \mathrm{~N}$ gas chromatograph (Agilent Technologies, Santa Clara, USA) equipped with flame ionization detector with a fused silica Supelcowax 10 capillary column $(30 \mathrm{~m} \times 0.25 \mathrm{~mm}$ i.d., $0.20 \mu \mathrm{m}$ film thickness). Split injection mode (1:50, v/v) was used, and helium was used as the carrier gas at a constant flow of $1.2 \mathrm{~mL} / \mathrm{min}$. The gradient temperature program started from $60{ }^{\circ} \mathrm{C}$, held for $2 \mathrm{~min}$, and raised, at $6^{\circ} \mathrm{C} / \mathrm{min}$ rate, up to $220^{\circ} \mathrm{C}$, held for $20 \mathrm{~min}$. The injector and the detector were set at 220 and $250^{\circ} \mathrm{C}$, respectively. Identification of the fatty acid methyl esters was carried out by comparison of their retention times with that of the standards and the quantities were calculated from the area obtained by the recorded integrator.

\subsection{Measurement of mineral element content}

Mineral element content was evaluated according to the method detailed by Tu et al. (2009) with slight modifications. In short, the sample $(500 \mathrm{mg})$ was weighed into a beaker, digested in $7 \mathrm{~mL}$ of $\mathrm{HNO}_{3}-\mathrm{H}_{2} \mathrm{O}_{2}(5: 2, \mathrm{v} / \mathrm{v})$ for $10 \mathrm{~min}$, and the mixture heated to near dryness. After cooling, the residue was treated with $0.1 \mathrm{M} \mathrm{HNO}_{3}$ and brought to $50 \mathrm{~mL}$ with bidistilled water. Mineral element was determined with an inductively coupled plasma-optical emission spectrometry (Teledyne Leeman Labs
Ltd., Prodigy, Hudson, NH, USA). Calibration curves of standard elements (sodium, potassium, calcium, zinc, magnesium, iron and manganese) were prepared and their contents in samples were calculated by regression equation.

\subsection{Statistical analysis}

The experimental results were expressed as means \pm standard deviation (SD) of triplicates. Statistical analysis was performed using Fisher's $F$-test and $p<0.05$ was regarded as significant.

\section{Results and discussion}

\subsection{Proximate composition of hot pepper seeds}

Proximate composition of hot pepper seeds is shown in Table 1. The moisture value in the powder of hot pepper seeds was $4.48 \mathrm{~g} / 100 \mathrm{~g}$. This value was close to those observed by other authors, such as Al-Jasass \& Al-Jasser (2012), who obtained moisture values of 4.68 and $4.36 \mathrm{~g} / 100 \mathrm{~g}$ for black pepper seeds (Piper nigrum) and mustard seeds (Sinapis alba). Ash, crude fat and crude protein contents were 4.94, 23.65 and $21.29 \mathrm{~g} / 100 \mathrm{~g}$, respectively. These values were higher $(p<0.05)$ than those found by Embaby \& Mokhtar (2011), who obtained values of 4.88 , 19.57 and $19.28 \mathrm{~g} / 100 \mathrm{~g}$ for hot pepper seeds. The differences in ash, crude fat and crude protein contents of various hot pepper seeds could be related to the individual genetical background or environmental influence. Chemical composition of plant was controlled by climate, soil and plant factors (Koyuncu et al., 2014). The same plant species might show different response to uptake of nutrients from the soil even when they were grown in the same conditions (Yildiz et al., 2014).

As one of food component, the dietary fiber is beneficial for human health. A number of studies reported by Elleuch et al. (2011) showed that the dietary fiber could prevent certain diseases such as colon cancer, obesity, cardiovascular problems and diabetes. As is shown in Table 1, the amount of total dietary fiber $(38.76 \mathrm{~g} / 100 \mathrm{~g})$ was higher $(p<0.05)$ than those of the other nutrients, which indicated that the dietary fiber was the main component of hot pepper seeds in this study. The dietary fiber content was related not only to the quantitative but also qualitative aspect since they were associated with polysaccharides with antioxidant activity (Sousa et al., 2014).

\subsection{Amino acid composition of hot pepper seeds}

Proteins and amino acids are essential for human health. Amino acids are required for the growth, development, regeneration and reconstruction of the body and are responsible for the

Table 1. Proximate composition of hot pepper seeds grown in Northeast Region of China.

\begin{tabular}{cc}
\hline Parameters & Result $(\mathrm{g} / 100 \mathrm{~g})$ \\
\hline Moisture & $4.48 \pm 0.18$ \\
Ash & $4.94 \pm 0.14$ \\
Crude fat & $23.65 \pm 0.41$ \\
Crude protein & $21.29 \pm 0.28$ \\
Total dietary fiber & $38.76 \pm 1.07$ \\
\hline
\end{tabular}


production of antibodies, blood cells, hormones and enzymes (Sousa et al., 2014). Amino acid composition of hot pepper seeds grown in the Northeast Region of China was analyzed and is given in Table 2. It was clear from the data that there were eighteen detectable amino acids in seed samples, which agreed with results reported by El-Adawy \& Taha (2001). Results also showed that the main amino acids of hot pepper seeds studied were glutamic acid and aspartic acid (above $2 \mathrm{~g} / 100 \mathrm{~g}$ ), followed by histidine, phenylalanine, lysine, arginine, cysteine, leucine, tryptophan, serine, glycine, methionine, threonine and tyrosine $(0.8-2 \mathrm{~g} / 100 \mathrm{~g})$. The contents of proline, alanine, valine and isoleucine (below $0.8 \mathrm{~g} / 100 \mathrm{~g}$ ) were the lowest, as compared to other amino acids. This result was similar to those previously reported by Embaby \& Mokhtar (2011).

The content of eight essential amino acids (threonine, valine, methionine, isoleucine, leucine, tryptophan, phenylalanine and lysine) in hot pepper seeds was $6.94 \mathrm{~g} / 100 \mathrm{~g}$. It accounted for $32.60 \%$ of the mass of crude protein, which indicated that the essential amino acid was one of the main components in hot pepper seeds. Therefore, amino acid composition of hot pepper seeds was beneficial for human health. Protein provided by hot pepper seeds might be used as an inexpensive nutrient source to meet the nutritional requirements of the Chinese population.

\subsection{Fatty acid profile of hot pepper seeds}

Lipids are one of the body's energy sources, and they provide fuel for the central nervous system and for the other organs of the human body (Sousa et al., 2014). Fatty acid profile of seed samples evaluated is given in Table 3 . The experimental results showed that linoleic acid $(16.82 \mathrm{~g} / 100 \mathrm{~g})$, palmitic acid $(3.31 \mathrm{~g} / 100 \mathrm{~g})$, oleic acid $(1.45 \mathrm{~g} / 100 \mathrm{~g})$, stearic acid $(0.61 \mathrm{~g} / 100 \mathrm{~g})$ and linolenic acid $(0.55 \mathrm{~g} / 100 \mathrm{~g})$ as the most abundant fatty acid followed lauric acid $(0.14 \mathrm{~g} / 100 \mathrm{~g})$, arachidic acid $(0.09 \mathrm{~g} / 100 \mathrm{~g})$, gondoic acid $(0.05 \mathrm{~g} / 100 \mathrm{~g})$ and behenic acid $(0.03 \mathrm{~g} / 100 \mathrm{~g})$. The current finding on fatty acid was compatible with those reported in previous published studies (Yang et al., 2010).

In lipids, unsaturated fatty acids (oleic acid, linoleic acid, linolenic acid and arachidic acid) have an important role in reducing blood cholesterol levels and improving treatment of atherosclerosis (Uchôa-Thomaz et al., 2014). Meanwhile, the essential fatty acids, including linoleic acid and linolenic acid, are indispensable for human health (Özcan \& Juhaimi, 2014). In present study, unsaturated fatty acid and essential fatty acid contents of hot pepper seeds were 18.91 and $17.37 \mathrm{~g} / 100 \mathrm{~g}$, which were markedly higher $(p<0.05)$ than those of cultivars ('California Wonder' and 'Aji Colorado') grown in United States (Jarret et al., 2013). The variations in the results could be explained by factors such as the variety and ripeness of the seeds studied.

\subsection{Mineral element content of hot pepper seeds}

Mineral is one of the most important nutritional quality factors in many crops and has many biological activities in the human body. Contents of sodium, potassium, calcium, zinc, magnesium, iron and manganese in hot pepper seeds were 12.38, 654.12, 174.71, 7.97, 237.59, 17.49 and $2.16 \mathrm{mg} / 100 \mathrm{~g}$, respectively (Table 4). In a similar study, Park et al. (2006) found that the most abundant mineral in hot pepper seeds was potassium, which agreed with the data obtained in this study. The level of potassium was higher $(p<0.05)$ than that of sodium, which could realize a mineral balance and favor hypertension control. Moreover, a diet rich in potassium could lower blood pressure and consequently the risk of morbidity and mortality due to cardiovascular diseases (Miele et al., 2015). In addition, potassium intake could decrease urinary calcium excretion and consequently reduce the risk of developing osteoporosis (Çetin et al., 2011).

Table 2. Amino acid composition of hot pepper seeds grown in Northeast Region of China.

\begin{tabular}{cc}
\hline Amino acid & Result $(\mathrm{g} / 100 \mathrm{~g})$ \\
\hline Aspartic acid & $2.03 \pm 0.07$ \\
Glutamic acid & $3.40 \pm 0.16$ \\
Serine & $0.86 \pm 0.05$ \\
Arginine & $1.01 \pm 0.05$ \\
Glycine & $0.82 \pm 0.04$ \\
Threonine & $0.81 \pm 0.05$ \\
Proline & $0.68 \pm 0.03$ \\
Alanine & $0.67 \pm 0.04$ \\
Valine & $0.49 \pm 0.02$ \\
Methionine & $0.82 \pm 0.03$ \\
Cysteine & $0.97 \pm 0.06$ \\
Isoleucine & $0.48 \pm 0.02$ \\
Leucine & $0.91 \pm 0.05$ \\
Tryptophan & $0.87 \pm 0.04$ \\
Phenylalanine & $1.26 \pm 0.08$ \\
Histidine & $1.62 \pm 0.07$ \\
Lysine & $1.03 \pm 0.06$ \\
Tyrosine & $0.80 \pm 0.04$ \\
\hline
\end{tabular}

Table 3. Fatty acid profile of hot pepper seeds grown in Northeast Region of China.

\begin{tabular}{cc}
\hline Fatty acid & Result $(\mathrm{g} / 100 \mathrm{~g})$ \\
\hline Lauric acid & $0.14 \pm 0.01$ \\
Palmitic acid & $3.31 \pm 0.07$ \\
Stearic acid & $0.61 \pm 0.02$ \\
Oleic acid & $1.45 \pm 0.04$ \\
Linoleic acid & $16.82 \pm 0.43$ \\
Linolenic acid & $0.55 \pm 0.02$ \\
Arachidic acid & $0.09 \pm 0.01$ \\
Gondoic acid & $0.05 \pm 0.01$ \\
Behenic acid & $0.03 \pm 0.01$ \\
\hline
\end{tabular}

Table 4. Mineral element content of hot pepper seeds grown in Northeast Region of China.

\begin{tabular}{cc}
\hline Mineral element & Result $(\mathrm{mg} / 100 \mathrm{~g})$ \\
\hline Sodium & $12.38 \pm 0.12$ \\
Potassium & $654.12 \pm 5.46$ \\
Calcium & $174.71 \pm 2.93$ \\
Zinc & $7.97 \pm 0.13$ \\
Magnesium & $237.59 \pm 3.63$ \\
Iron & $17.49 \pm 0.25$ \\
Manganese & $2.16 \pm 0.05$ \\
\hline
\end{tabular}


The minerals calcium, iron and zinc are considered essential for the human body. Calcium is one of the most important compositions in human bone. Iron is associated with the production of blood cells and zinc is essential for the immune system (Sousa et al., 2014). As is shown in Table 4, the contents of calcium, iron and zinc of hot pepper seeds were $174.71,17.49$ and $7.97 \mathrm{mg} / 100 \mathrm{~g}$, which were approximately 1.07-1.20 times higher than the values of hot pepper seeds reported by

El-Adawy \& Taha (2001). It was important to note that the intake of the minerals, particularly calcium, iron and zinc, was often low in the Chinese diet (Jiang et al., 2015). The consumption of food products used hot pepper seeds as an ingredient could increase the amount of minerals in the daily diet.

\section{Conclusions}

Hot pepper seeds grown in the Northeast Region of China were evaluated in relation to proximate composition, amino acid composition, fatty acid profile and mineral element content. The proximate analysis showed the following composition: moisture $4.48 \mathrm{~g} / 100 \mathrm{~g}$, ash $4.94 \mathrm{~g} / 100 \mathrm{~g}$, crude fat $23.65 \mathrm{~g} / 100 \mathrm{~g}$, crude protein $21.29 \mathrm{~g} / 100 \mathrm{~g}$ and total dietary fiber $38.76 \mathrm{~g} / 100 \mathrm{~g}$. There were eighteen detectable amino acids in pepper seed samples. The fatty acid profile showed that linoleic acid, palmitic acid, oleic acid, stearic acid and linolenic acid as the most abundant fatty acid followed lauric acid, arachidic acid, gondoic acid and behenic acid. Analyses of mineral content indicated that the most abundant mineral in hot pepper seeds was potassium, followed by magnesium, calcium, iron, zinc, sodium and manganese. Results from present study showed that hot pepper seeds were an inexpensive and effective dietary supplement for improving human health.

\section{Acknowledgements}

This work was supported by the National Natural Science Foundation of China (No. 31301814).

\section{References}

Aberoumand, A. (2014). Preliminary studies on nutritive and organoleptic properties in processed fish fillets obtained from Iran. Food Science and Technology, 34(2), 287-291. http://dx.doi.org/10.1590/fst.2014.0042.

Al-Jasass, F. M., \& Al-Jasser, M. S. (2012). Chemical composition and fatty acid content of some spices and herbs under Saudi Arabia conditions. TheScientific WorldJournal, 2012, 859892. http://dx.doi. org/10.1100/2012/859892. PMid:23319888.

Bae, H., Jayaprakasha, G. K., Jifon, J., \& Patil, B. S. (2012). Variation of antioxidant activity and the levels of bioactive compounds in lipophilic and hydrophilic extracts from hot pepper (Capsicum spp.) cultivars. Food Chemistry, 134(4), 1912-1918. http://dx.doi. org/10.1016/j.foodchem.2012.03.108. PMid:23442638.

Çetin, E. S., Altinöz, D., Tarçan, E., \& Baydar, N. G. (2011). Chemical composition of grape canes. Industrial Crops and Products, 34(1), 994-998. http://dx.doi.org/10.1016/j.indcrop.2011.03.004.

El-Adawy, T. A., \& Taha, K. M. (2001). Characteristics and composition of different seed oils and flours. Food Chemistry, 74(1), 47-54. http:// dx.doi.org/10.1016/S0308-8146(00)00337-X.
Elleuch, M., Bedigian, D., Roiseux, O., Besbes, S., Blecker, C., \& Attia, H. (2011). Dietary fibre and fibre-rich by-products of food processing: characterisation, technological functionality and commercial applications: A review. Food Chemistry, 124(2), 411-421. http:// dx.doi.org/10.1016/j.foodchem.2010.06.077.

Embaby, H. E., \& Mokhtar, S. M. (2011). Chemical composition and nutritive value of lantana and sweet pepper seeds and nabak seed kernels. Journal of Food Science, 76(5), C736-C741. http://dx.doi. org/10.1111/j.1750-3841.2011.02166.x. PMid:22417420.

Firatligil-Durmus, E., \& Evranuz, O. (2010). Response surface methodology for protein extraction optimization of red pepper seed (Capsicum frutescens). LWT - Food Science and Technology, 43(2), 226-231. http://dx.doi.org/10.1016/j.lwt.2009.08.017.

Hartman, L., \& Lago, R. C. (1973). Rapid preparation of fatty acid methyl esters from lipids. Laboratory Practice, 22(6), 475-476. PMid:4727126.

Herch, W., Kallel, H., \& Boukhchina, S. (2014). Physicochemical properties and antioxidant activity of Tunisian date palm (Phoenix dactylifera L.) oil as affected by different extraction methods. Food Science and Technology, 34(3), 464-470. http://dx.doi.org/10.1590/1678-457x.6360.

Jarret, R. L., Levy, I. J., Potter, T. L., \& Cermak, S. C. (2013). Seed oil and fatty acid composition in Capsicum spp. Journal of Food Composition and Analysis, 30(2), 102-108. http://dx.doi.org/10.1016/j. jfca.2013.02.005.

Jiang, J., Lu, S., Zhang, H., Liu, G., Lin, K., Huang, W., Luo, R., Zhang, X., Tang, C., \& Yu, Y. (2015). Dietary intake of human essential elements from a total diet study in Shenzhen, Guangdong Province, China. Journal of Food Composition and Analysis, 39, 1-7. http:// dx.doi.org/10.1016/j.jfca.2014.10.012.

Koyuncu, F., Çetinbaş, M., \& Ibrahim, E. (2014). Nutritional constituents of wild-grown black mulberry (Morus nigra L.). Journal of Applied Botany and Food Quality, 87(1), 93-96. http://dx.doi.org/10.5073/ jabfq.2014.087.014.

Miele, A., Rizzon, L. A., Queiroz, S. C. N., \& Gianello, C. (2015). Physicochemical composition, minerals, and pesticide residues in organic grape juices. Food Science and Technology, 35(1), 120-126. http://dx.doi.org/10.1590/1678-457X.6540.

Özcan, M. M., \& Juhaimi, F. A. (2014). Effect of sprouting and roasting processes on some physico-chemical properties and mineral contents of soybean seed and oils. Food Chemistry, 154(1), 337-342. http:// dx.doi.org/10.1016/j.foodchem.2013.12.077. PMid:24518351.

Park, H., Lee, S., Jeong, H., Cho, S., Chun, H., Back, O., Kim, D., \& Lillehoj, H. S. (2006). The nutrient composition of the herbicidetolerant green pepper is equivalent to that of the conventional green pepper. Nutrition Research, 26(10), 546-548. http://dx.doi. org/10.1016/j.nutres.2006.09.001.

Prosky, L., Asp, N. G., Schweizer, T. F., DeVries, J. W., \& Furda, I. (1988). Determination of insoluble, soluble, and total dietary fiber in foods and food products: interlaboratory study. Journal - Association of Official Analytical Chemists, 71(5), 1017-1023. PMid:2853153.

Sousa, E. C., Uchôa-Thomaz, A. M. A., Carioca, J. O. B., Morais, S. M., Lima, A., Martins, C. G., Alexandrino, C. D., Ferreira, P. A. T., Rodrigues, A. L. M., Rodrigues, S. P., Silva, J. N., \& Rodrigues, L. L. (2014). Chemical composition and bioactive compounds of grape pomace (Vitis vinifera L.), Benitaka variety, grown in the semiarid region of Northeast Brazil. Food Science and Technology, 34(1), 135-142.

Tu, Y., Sun, Y., Tian, Y., Xie, M., \& Chen, J. (2009). Physicochemical characterisation and antioxidant activity of melanin from the muscles of Taihe Black-bone silky fowl (Gallus gallus domesticus Brisson). Food Chemistry, 114(4), 1345-1350. http://dx.doi.org/10.1016/j. foodchem.2008.11.015. 
Uchôa-Thomaz, A. M. A., Sousa, E. C., Carioca, J. O. B., Morais, S. M., Lima, A., Martins, C. G., Alexandrino, C. D., Ferreira, P. A. T., Rodrigues, A. L. M., Rodrigues, S. P., Thomaz, J. C. A., Silva, J. N., \& Rodrigues, L. L. (2014). Chemical composition, fatty acid profile and bioactive compounds of guava seeds (Psidium guajava L.). Food Science and Technology, 34(3), 485-492. http://dx.doi. org/10.1590/1678-457x.6339.

Yang, C. Y., Mandal, P. K., Han, K. H., Fukushima, M., Choi, K., Kim, C. J., \& Lee, C. H. (2010). Capsaicin and tocopherol in red pepper seed oil enhances the thermal oxidative stability during frying. Journal of Food Science and Technology, 47(2), 162-165. http://dx.doi. org/10.1007/s13197-010-0032-2. PMid:23572619.

Yildiz, H., Ercisli, S., Hegedus, A., Akbulut, M., Topdas, E. F., \& Aliman, J. (2014). Bioactive content and antioxidant characteristics of wild (Fragaria vesca L.) and cultivated strawberry (Fragaria $\times$ ananassa Duch.) fruits from Turkey. Journal of Applied Botany and Food Quality, 87(1), 274-278. http://dx.doi.org/10.5073/ jabfq.2014.087.038. 